\title{
Interaksi Ekstrak Etanol Biji Nigella sativa Terhadap Bakteri Probiotik dan Patogen
}

\author{
Ahmad Shobrun Jamil \\ Program Studi Farmasi Fakultas Ilmu Kesehatan Universitas Muhammadiyah Malang \\ Jl. Bendungan Sutami 188 A Tlp +62 341 551149; +62 341582060 \\ Email: jamilspeed@gmail.com
}

\begin{abstract}
Nigella sativa seed has a lot of beneficial health effect, such as immune-modulator, anti-histamine, anti-diabetic, anti-hypertension, anti-inflammatory, anti-microbes and antitumor. Numeral antimicrobial effect of Nigella sativa has been published, but only a few number of the information of the antimicrobial activity to the probiotic bacteria such as from the genus of Lactobacillus spp. However this research focused on the selectivity of the antimicrobial activity of $\mathrm{N}$. sativa extract to the probiotic and pathogenic bacteria. This research begins with the extraction of $\mathrm{N}$. sativa seed powder by ethanol $80 \% 1: 3(\mathrm{w} / \mathrm{v})$. With rotary evaporator the macerates extracted till gained semi solid extract. In the other side probiotic and pathogenic bacteria broth cultures were prepared. Extract resoluted with concentration 5\%; 2,5\%; 1,25\% and $0,625 \%$. Into the extract were submerged some disk paper with $6 \mathrm{~mm}$ diameter. After that the disk put on to the solid medium were had cultured by bacteria then incubated overnight. The diameters of the clearing zone that seemed then measured. The result showing that the inhibitory zone occurred at $0,625 \%$ concentration. After general analysis there is no significant different inhibitory effect of the extract to the tested bacteria, but from the statistical analysis known that probiotik bacteria seemed more sensitive than pathogenic bacteria were tested.
\end{abstract}

Key Word: pathogenic bacteria, probiotic bacteria, extract, $N$. sativa, inhibitory zone

\begin{abstract}
ABSTRAK
Aktivitas antimikroba dari biji tumbuhan Nigella sativa telah banyak dibuktikan dalam penelitian. Namun masih sedikit penelitian yang berkaitan dengan aktivitas antibiotik $N$. Sativa terhadap flora normal dalam saluran pencernakan manusia salah satunya adalah bakteri probiotik Lactobacillus spp. Oleh karena itu penelitian ini dilaksanakan untuk mengetahui selektivitas aktivitas antimikroba ekstrak etanol biji $N$. sativa terhadap bakteri probiotik dan patogen. Penelitian dilaksanakan dengan beberapa tahap pengerjaan. Pertama, ekstraksi serbuk biji $N$. sativa dengan ethanol $80 \% \quad 3: 1(\mathrm{w} / \mathrm{v})$. Kemudian ketiga disiapkan ekstrak dengan konsentrasi $5 \% ; 2,5 \% ; 1,25 \%$ dan $0,625 \%$. Kedalam masing-masing ekstrak direndam cakram kertas dengan diameter $6 \mathrm{~mm}$. Selanjutnya biakan bakteri digoreskan di medium dalam cawan. Selanjutnya dilaksanakan uji difusi cakram dengan meletakkan cakram yang telah terendam dalam ekstrak dalam cawan berisi biakan bakteri kemudian cawan diinkubasi suhu $37^{\circ} \mathrm{C}$ selama 24 jam. Hasil pengamatan diketahui zona hambat sudah teramati pada konsentrasi $0,625 \%$. Secara umum tidak ada beda nyata rata-rata diameter zona hambat antar bakteri uji hanya diketahui dari analisis statistik bahwa bakteri probiotik lebih sensitif terhadap senyawa dalam ekstrak dibandingkan dengan bakteri patogen yang diujikan.
\end{abstract}

Kata Kunci: bakteri patogen, bakteri probiotik, Ekstrak, Nigella sativa, zona hambat. 


\section{Latar Belakang}

Nigella sativa dipercaya masyarakat Asia khususnya Timur Tengah dan Asia Tenggara memiliki khasiat pengobatan yang sangat banyak. Hal ini didasari oleh pengetahuan dan keyakinan masyarakat terhadap sabda Nabi Muhammad (Shallalahu 'alaihi wa sallam) yang menyatakan bahwa "Habbatus sauda' (Nigella sativa) adalah obat dari segala penyakit kecuali kematian". Perkembangan teknologi membuktikan hal ini dengan sejumlah penelitian yang menunjukkan khasiat pengobatan berbagai macam penyakit. Menurut Mbarek et al. (2007) N . sativa memiliki khasiat diantaranya adalah stimulan peningkat imunitas tubuh, antihistamin, anti-diabetes, anti-hipertensi, anti inflamasi, antimikroba, dan antitumor. Berdasarkan pengetahuan tentang manfaat $N$. sativa tersebut, saat ini masyarakat telah banyak memanfaatkannya sebagai alternatif terapi pengobatan.

Bukti-bukti ilmiah tersebut menjadikan masyarakat semakin terpacu untuk mengkonsumsi biji Nigella sativa Sehingga $N$. sativa yang pada awalnya dikonsumsi untuk terapi suatu penyakit berubah pola konsumsinya menjadi makanan suplemen. Masyarakat bahkan memanfaatkan $N$. sativa sebagai suplemen makanan yang diminum setiap hari dengan dosis yang relatif tinggi.

Mengingat berbagai penelitian membuktikan bahwa $N$. sativa memiliki aktivitas antibakteri dan bahkan sebagian bahan antibiotika memiliki efek letal yang lebih tinggi jika dikombinasikan dengan minyak $N$. sativa maka perlu dicari konsentrasi aman untuk menghindari efek negatif $N$. sativa terhadap bakteri probiotik dalam saluran pencernakan, akibat penggunaan yang berlebihan. Terkait efek antimikroba, $N$ sativa dapat disebut sebagai bahan anti mikrobia dengan spektrum yang cukup luas. Hal ini didukung oleh beberapa penelitian yang menunjukkan bahwa ekstrak $N$. sativa mampu mematikan bakteri patogen Gram positif dan negatif seperti Escherichia coli, Pseudomonas aeruginosa, Shigella flexneri, Salmonella typhimurium, Salmonella enteritidis dan Staphylococcus aureus (Ali et al., 2007., Halawani, 2009., Abu-Zinadah, 2009). Hal ini menjadi salah satu indikator bahwa penggunaan $N$. sativa sebagai bahan terapi pengobatan dan suplemen makanan memerlukan dosis yang tepat untuk menghindari efek negatif yang kemungkinan muncul.

Salah satu efek negatif yang dikhawatirkan muncul dari penggunaan Nigella sativa yang berlebihan adalah terganggunya kestabilan flora normal, termasuk bakteri probiotik di dalam saluran pencernakan akibat aktivitas antimikrobia dari N. sativa. Padahal bakteri probiotik memiliki peranan yang penting di dalam saluran pencernakan manusia. Menurut Crittenden et al. (2005) diketahui bahwa bakteri probiotik berinteraksi dengan inang di dalam saluran percernakan dalam bentuk perlindungan terhadap bakteri enteropatogen dengan cara resistensi koloni, disamping memberi manfaat pada inang dalam hal penyediaan nutrisi dan kesehatan usus melalui aktivitas metabolismenya. Selain itu, bakteri probiotik dapat berinteraksi dengan sistem imun tubuh sehingga terjadi kestabilan dan homeostasis sistem imun tubuh.

Saat ini informasi hasil penelitian yang berkaitan dengan efek $N$. sativa terhadap bakteri probiotik masih sangat terbatas. Oleh karena itu, untuk menghindari efek negatif penggunaan $N$. sativa terhadap stabilitas bakteri probiotik dalam saluran 
pencernakan akibat konsumsi yang berlebihan, maka diperlukan pengetahuan konsentrasi $N$. sativa yang tepat bagi bakteri probiotik.

Berdasarkan latar belakang tersebut maka penelitian ini bertujuan untuk mengetahui efek paparan ekstrak biji $N$. sativa terhadap viabilitas bakteri probiotik.

\section{Metode Penelitian}

Bahan

Bakteri probiotik: Lactobacillus acidophilus dan Lactobacillus spp. Didapatkan dari laboratorium mikrobiologi Fakultas Kedokteran Universitas Brawijaya Malang. Serbuk biji Nigella sativa didapatkan secara komersial di toko bahan obat herbal di Malang. Aquades, Etanol 95\%, Cakram Antibiotik, Kertas saring Whattmann, Medium MRSA Merck, Medium Nutrient broth Merck, disediakan oleh laboratorium kimia FIKES dan biomedik FK Universitas Muhammadiyah Malang.

\section{Ekstraksi Biji N. sativa}

Prosedur persiapan ekstrak Nigella sativa adalah modifikasi metode Farah (2005). Serbuk N. sativa diekstrak dengan pelarut etanol secara maserasi. Sebanyak 50 g bubuk $N$ sativa ditambah dengan $150 \mathrm{ml}$ etanol $80 \%$ kemudian dihomogenasi. Larutan disimpan dalam refrigerator suhu $4^{\circ} \mathrm{C}$ dalam waktu semalam. Ekstrak $N$. sativa dalam etanol kemudian dipekatkan dalam Rotary Evaporator suhu $40^{\circ} \mathrm{C}$. Selanjutnya ekstrak diuapkan dalam oven $60^{\circ} \mathrm{C}$ hingga didapat ekstrak semi padat. Hasil ekstrak etanol selanjutnya diencerkan secara berseri dengan aquades dan DMSO $1 \%$ sehingga didapatkan fraksi pengenceran $5 \% ; 2,5 \% ; 1,25 \%$ dan $0,625 \%$. Pada masing-masing konsentrasi dimasukkan kertas berbentuk cakram berdiameter $6 \mathrm{~mm}$.

\section{Persiapan Bakteri Uji}

Bakteri probiotik, Lactobacillus acidophyllus dan Lactobacillus spp. sebanyak 5 ose diinokulasikan ke dalam 50 ml MRS Broth. Bakteri patogen, Salmonella spp. dan Staphylococcus spp. sebanyak 5 ose diinokulasikan dalam $50 \mathrm{ml}$ Nutrien Broth (NB). Keempat biakan selanjutnya diinkubasi selama 24 jam dalam suhu $37^{\circ} \mathrm{C}$.

\section{Uji Difusi Cakram}

Empat strain bakteri starter masingmasing dikulturkan dalam medium padat dalam cawan petri. Medium MRSA dalam cawan untuk bakteri probiotik dan di medium Nutrien Agar untuk bakteri patogen. Selanjutnya dilaksanakan uji difusi cakram dengan meletakkan cakram yang telah terendam dalam ekstrak dalam cawan berisi biakan bakteri kemudian cawan diinkubasi suhu $37^{\circ} \mathrm{C}$ selama 24 jam. Selanjutnya dilaksanakan pengukuran diameter zona hambat untuk masing-masing konsentrasi ekstrak pada masing-masing strain bakteri yang diujikan.

\section{Analisis Data}

Setelah hasil diketahui maka dilakukan analisis statistik dengan analisis ragam, regresi dan korelasi sehingga diketahui konsentrasi minimum Nigella sativa yang memiliki efek letal terhadap bakteri uji.

\section{Hasil dan Pembahasan}

Hasil pengujian aktivitas ekstrak serbuk biji N. Sativa terhadap bakteri probiotik dan enteropatogen diketahui bahwa ekstrak tersebut memiliki efek penghambatan terhadap pertumbuhan koloni 
mikroba baik golongan probiotik (Lactobacillus acidophyllus dan Lactobacillus spp.) dan bakteri enteropatogen (Staphyllococcus aureus dan Salmonella spp.). Sehingga dapat dinyatakan bahwa aktivitas antimikroba ekstrak etanol biji $N$. sativa berspektrum luas dan tidak selektif pada mikroba patogen saja Tabel 1. menunjukkan hal tersebut, dimana pada setiap perlakuan mulai dari konsentrasi terendah sampai dengan konsentrasi tertinggi yang diujikan masingmasing menunjukkan bahwa ekstrak etanol $N$. sativa memiliki daya hambat pertumbuhan mikroba.

Berdasarkan hasil pengamatan dan analisis statistik diketahui bahwa ekstrak etanol biji $N$. sativa mulai berpengaruh terhadap pertumbuhan mikroba uji pada konsentrasi 0,625\% pada bakteri patogen yaitu. S. aureus kemudian Salmonella spp..

Tabel 1. Diameter zona hambat pertumbuhan bakteri dengan uji difusi cakram berisi ekstrak etanol biji nigella sativa yang diujikan pada bakteri probiotik dan bakteri patogen

\begin{tabular}{lcccc}
\hline & \multicolumn{4}{c}{ Konsentrasi Ekstrak Etanol Biji Nigella sativa (\%) } \\
& $\mathbf{0 , 6 2 5}$ & $\mathbf{1 , 2 5}$ & $\mathbf{2 , 5}$ & $\mathbf{5}$ \\
\hline Bakteri Probiotik & & & & \\
Lactobacilhus spp & $6,00^{*} \pm 0,96$ & $7,13 \pm 0,81$ & $7,47 \pm 1,40$ & $7,78 \pm 0,01$ \\
Lactobacillus acidophyllus & $6,52 \pm 2,08$ & $7,22 \pm 2,00$ & $8,63 \pm 1,16$ & $10,45 \pm 0,32$ \\
Bakteri Patogen/Pencemar Makanan & & & & \\
Staphyllococcus aureus & $8,23 \pm 0,13$ & $8,32 \pm 0,96$ & $8,70 \pm 0,80$ & $9,25 \pm 0,29$ \\
Salmonella spp & $7,43 \pm 0,76$ & $7,50 \pm 0,40$ & $7,53 \pm 0,01$ & $8,33 \pm 0,12$ \\
\hline
\end{tabular}

Keterangan: "diameter cakram $6 \mathrm{~mm}$, sehingga aktivitas hambatan dapat dikatakan negatif apabila diameter zona hambatan kurang dari sama dengan $6 \mathrm{~mm}$.

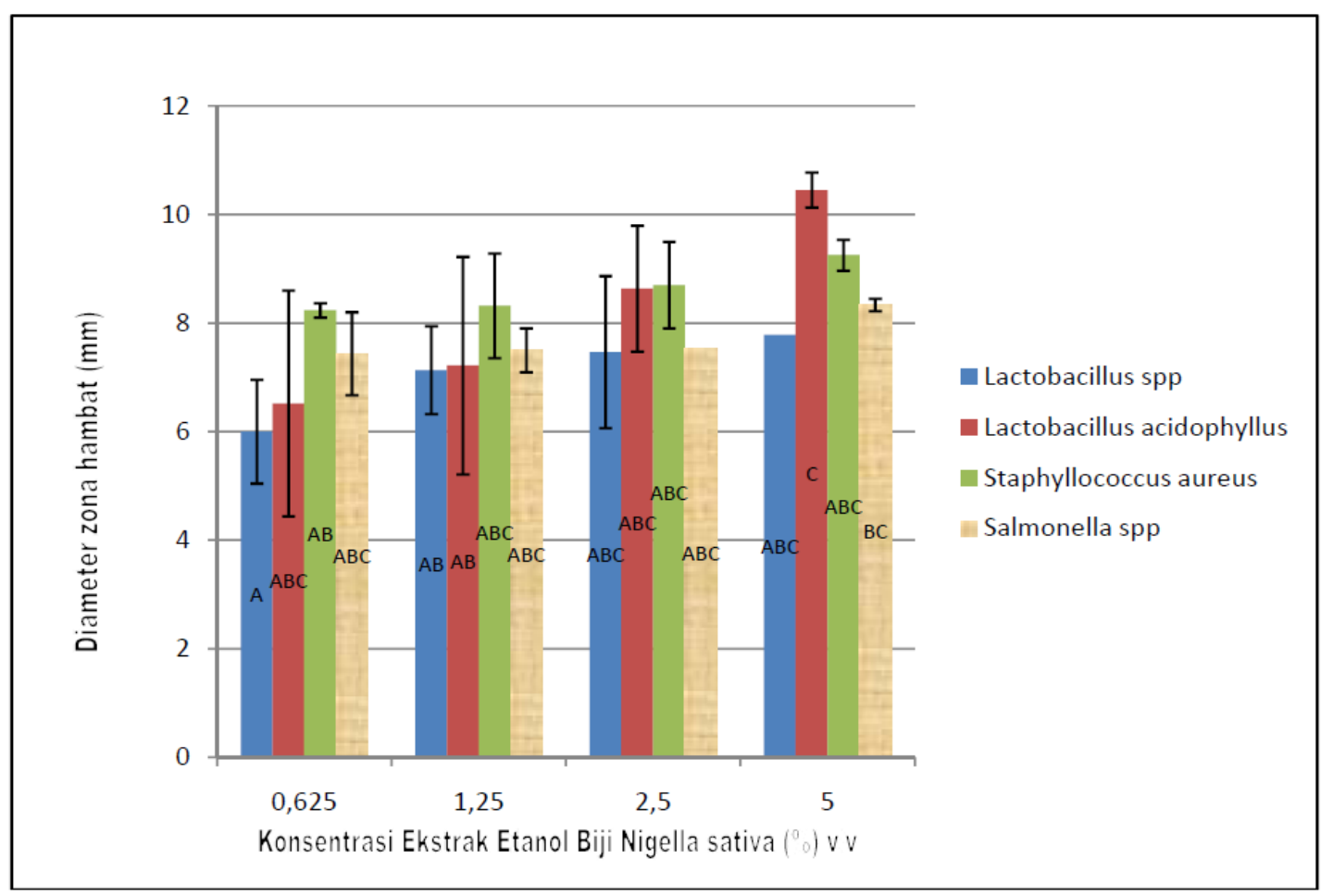

Gambar 1. Respon penghambatan pertumbuhan bakteri uji terhadap ekstrak etanol biji Nigella sativa 
Tabel 2. Perbandingan efektivitas metode ekstraksi serbuk biji $N$. sativa terhadap aktivitas penghambatan pertumbuhan koloni mikroba.

\begin{tabular}{|c|c|c|c|c|c|}
\hline No & Bakteri & $\begin{array}{c}\text { Metode Elistraksi } N \text {. } \\
\text { safiva }\end{array}$ & Konsentrasi & $\begin{array}{l}\text { Diameter Zona } \\
\text { Hambat (mm) }\end{array}$ & Peneliti \\
\hline 1 & Salmonella spp & $\begin{array}{l}\text { soluxlet extraction, } \mathrm{N}_{-} \\
\text {hexan }\end{array}$ & $2 \%$ & 24,5 & Arici, 2005 \\
\hline 2 & Salmonella typhi & stem distillation on & $600 \mu g / d i s k$ & 19 & Aral, 2005 \\
\hline 3 & Salmonella typhii & $\begin{array}{l}\text { Clevengger Apparatus } \\
\text { stem distillation on } \\
\text { Clevengger Apparatus }\end{array}$ & $20 \mu \mathrm{g} / \mathrm{disk}$ & 10 & Gerige, 2009 \\
\hline 4 & Salmonella spp & Maceration, ethanol & $5 \%$ & 8,33 & Penelitian ini \\
\hline 1 & Staphylococcus aureus & $\begin{array}{l}\text { sohxlet extraction, N- } \\
\text { hexan }\end{array}$ & $2 \%$ & 29,5 & Arici, 2005 \\
\hline 2 & Staphylococcus aureus & $\begin{array}{l}\text { stem distillation on } \\
\text { Clevengger Apparatus }\end{array}$ & $600 \mu \mathrm{g} / \mathrm{disk}$ & 24 & Aral, 2005 \\
\hline 3 & $\begin{array}{l}\text { Meticillin resisten } \\
\text { Staphylococcus aureus }\end{array}$ & $\begin{array}{l}\text { Supercritical Fluid } \\
\text { Extraction }\end{array}$ & $6,25 \%$ & $\begin{array}{l}\text { tidak ada zona } \\
\text { hambat/resisten }\end{array}$ & Alhajj, 2008 \\
\hline 4 & Staphylococcus aureus & $\begin{array}{l}\text { stem distillation on } \\
\text { Clevengger Apparatus }\end{array}$ & $20 \mu \mathrm{g} / \mathrm{disk}$ & 18 & Gerige, 2009 \\
\hline 5 & Staphylococcus aureus & Maceration, ethanol & $5 \%$ & 9,25 & Penelitian ini \\
\hline
\end{tabular}

Hasil ini tidak jauh berbeda dengan penelitian yang telah dilaksanakan oleh Arici et al. (2005) yang menggunakan minyak biji $N$. sativa didapatkan, konsentrasi minimum yang berpengaruh terhadap mikroba patogen yang diuji ada pada konsentrasi $0,5 \%$. Adapun pada konsentrasi berikutnya $(1,25 \%)$ ekstrak $N$. sativa tampak menghambat pertumbuhan dua strain bakteri probiotik sekaligus dua strain bakteri patogen yang diujikan dalam penelitian ini.

Berdasarkan hasil analisis statistik pada konsentrasi $0,625 \%$ diketahui senyawa dalam ekstrak $N$. sativa sudah menunjukkan aktivitas penghambatan pada bakteri patogen Staphylococcus aureus dan Salmonella spp. serta satu strain bakteri probiotik yaitu Lactobacillus acidophyllus. Namun senyawa ekstrak $N$. sativa tersebut tidak menunjukkan efek penghambatan pada bakteri Lactobacillus spp. Adapun pada konsentrasi $1,25 \%$ dan 2,5\% ekstrak tampak menunjukkan efek penghambatan yang sama pada semua strain bakteri uji. Dan pada konsentrasi 5\% tampak bahwa salah satu strain bakteri probiotik $L$. acidophyllus mengalami efek penghambatan paling tinggi dibanding strain bakteri uji yang lain. Hal ini mengindikasikan bahwa semakin tinggi konsentrasi ekstrak dapat memberikan efek penghambatan pertumbuhan bakteri probiotik lebih tinggi dibanding bakteri patogen. Secara keseluruhan berdasarkan data hasil analisis ini semakin memperkuat dugaan bahwa ekstrak biji $N$. sativa memiliki aktivitas antimikroba yang tidak selektif dan cenderung berspektrum luas.

Oleh karena hasil penelitian menunjukkan efek penghambatan pertumbuhan yang cenderung lebih tinggi terhadap bakteri probiotik daripada bakteri patogen, maka perlu dipertimbangkan penggunaan dosis yang aman untuk konsumsi $N$. sativa sebagai suplemen kesehatan. Hal ini disebabkan karena selama ini di masyarakat cenderung belum ada aturan pakai yang didasarkan atas pertimbangan keseimbangan flora normal di tubuh.

Gerige et al. (2009), menyebutkan bahwa terkait sensitivitas bakteri terhadap 
senyawa aktif dalam biji $N$. sativa, bakteri Gram negatif adalah golongan bakteri yang lebih sensitif dibandingkan dengan bakteri Gram positif. Adanya senyawa á-thujene, 2(1H)-naphthalenone, a-pinene, aphellandrene, limonene, thymoquinone, myristicin dalam biji $N$. sativa adalah senyawa-senyawa yang berkontribusi memunculkan aktivitas antimikroba.

Apabila dibandingkan dengan pengujian yang lain, diketahui bahwa dari beberapa hasil penelitian diketahui bahwa aktivitas penghambatan ekstrak etanol biji $N$. sativa dalam penelitian ini relatif rendah. Sehingga dapat direkomendasikan ekstraksi menggunakan soxhlet dan pelarut $\mathrm{N}$-heksan dirasa lebih efektif mengekstraksi senyawa aktif dibandingkan dengan etanol, sebagaimana hasil yang tertera pada Tabel 2.

\section{Kesimpulan}

Berdasarkan hasil uji dan analisis statistik efek penghambatan pertumbuhan bakteri dengan penambahan ekstrak $N$. sativa diketahui bahwa ekstrak etanol $N$. sativa memiliki aktivitas antimikroba yang bersifat spektrum luas dan tidak selektif. Selain itu diketahui bahwa ekstrak $N$. sativa memiliki aktivitas penghambatan pertumbuhan yang cenderung lebih tinggi pada bakteri probiotik dibandingkan dengan bakteri patogen. Dan diketahui pula bahwa metode ekstraksi dengan maserasi kurang efektif mengekstrak senyawa dalam biji $N$. sativa dibandingkan dengan ekstraksi uap menggunakan Soxhlet.

\section{Ucapan Terimakasih}

Ucapan terimakasih dan penghargaan disampaikan kepada DP2M UMM yang telah memberikan pendanaan sehingga penelitian in dapat dilaksanakan.

\section{Daftar Pustaka}

Abu-Zinadah, O. A. 2009. Using Nigella sativa Oil to Treat and Heal Chemical Induced Wound of Rabbit Skin. JKAU: Sci., Vol.

21 No. 2, pp: 335-346.

Ali, O., G. Basbullbul, T. Aydin. 2007. Antimitotic and antibacterial effects of the Nigella sativa $L$. Seed. Caryologia. 60(3): 270272.

Arici, M., O. Sagdic, U. Gecgel1. 2005. Antibacterial effect of Turkish black cumin (Nigella sativa L.) oils. Grasas y Aceites Vol. 56.

Fasc. 4, 259-262

Ara1, N., S A R Choudhury, R. Amin. 2005. In vitro Antimicrobial Activity of the Volatile Oil of Nigella Sativa Linn Seeds. The Journal of Teachers Association RMC. Rajshahi. Volume 18 Number 2.

Alhaj, N. A., M. N. Shamsudin, H. F. Zamri, R. Abdullah. 2008. Extraction of Essential Oil from Nigella sativa Using Supercritical Carbon Dioxide: Study of Antibacterial Activity.

American Journal of Pharmacology and Toxicology 3 (4): 225-228.

Crittenden, R., A.R. Bird, P. Gopal, A. Henriksson, Y.K. Lee, M.J. Playne. 2005. Probiotic Research in Australia, New Zealand and the Asia-Pacific Region. Current Pharmaceutical Design (11): 37-53. 
Gerige, S. J, M. Kumar, Y. Gerige, M.

Rao, Ramanjaneyulu. 2009.

GC-MS Analysis of Nigella

sativa Seeds and Antimicrobial

Activity of its Volatile oil.

Brazilian Archives Of Biology

And Technology. Vol.52, n. 5:

1189-1192.

Halawani, E. 2009. Antibacterial Activity

of Thymoquinone and

Thymohydroquinone of Nigella

sativa L. and Their Interaction

with Some Antibiotics.

Advances in Biological

Research 3 (5-6): 148-152.

Mbarek, L. A., H. A. Mouse, N. Elabbadi,

M. Bensalah, A. Gamouh, R.

Aboufatima, A. Benharref, A.

Chait, M. Kamal, A. Dalal, A.

Zyad. 2007. Anti-tumor

properties of blackseed

(Nigella sativa L.) extracts.

Braz J Med Biol Res. 